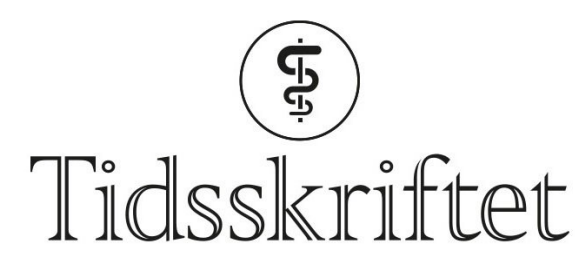

DEN NORSKE LEGEFORENING

\title{
Ernst Arne Høiby
}

MINNEORD

STEIN KVALøY

HARALD HOLTE

DAG TORFOSS

ELDBJØRG VORKINN

SUNNIVA FAGERÅS RØST

SIGBJØRN SMELAND

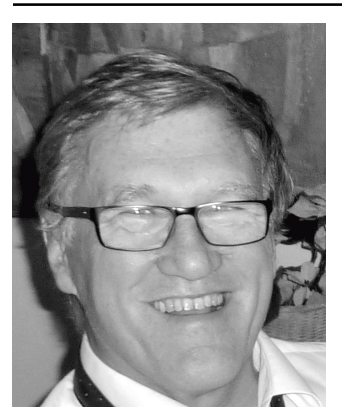

Vår gode venn og kollega overlege Ernst Arne Høiby døde 19. mars, 74 år gammel. Han var i mange år en av de tre i teamet fra Folkehelseinstituttet som bidro med mikrobiologisk ekspertise for Radiumhospitalets pasienter. Arne var en svært godt klinisk orientert mikrobiolog. Da Radiumhospitalet i 1987 etablerte høydosebehandling med autolog stamcellestøtte (HMAS), bidro han sterkt til planene for diagnostikk og behandling av de alvorlige infeksjonene som oppstår i forbindelse med denne behandlingen. Hans bidrag $\mathrm{i}$ den tidlige fasen var viktig for at dette prosjektet ble gjennomført på en god måte. HMAS er fortsatt standardbehandling for flere pasientgrupper. På laboratoriet delte han raust av sin kunnskap. Med sin gode formidlingsevne sørget han for å holde sine medarbeidere godt oppdatert i faget.

Arne var opptatt av å forebygge antibiotikaresistens, og han bidro til god antibiotikapraksis gjennom sine råd og boken Antimikrobielle midler: grunnlag for fornuftig bruk. Etter fusjonen med Rikshospitalet fortsatte han både som doktorgradsveileder og som medforfatter av sykehusets lommehåndbøker Diagnostikk og behandling av infeksjoner hos pasienter med kreft.

Arne var en intellektuell person med mange interesser, som språk og historie, mat og vin. 
Han var en mester i å fortelle historier som han gjerne delte med oss, og vi vil huske hans humoristiske sans. Han sørget for korrekt språk og tegnsetting i de mange vitenskapelige artiklene han var medforfatter av. Arne fulgte med på virksomheten vår, og han var stadig innom Radiumhospitalet, også helt til det siste.

Våre tanker og vår medfølelse går til hans familie. Vi lyser fred over hans minne.

Publisert: 15. juni 2020. Tidsskr Nor Legeforen. DOI: 10.4045/tidsskr.20.0335

C Tidsskrift for Den norske legeforening 2020. Lastet ned fra tidsskriftet.no 